Environment Conservation Journal 15(1 \&2) 117-121, 2014

ISSN 0972-3099 (Print) 2278-5124 (Online)

Abstracted and Indexed

\title{
Effects of Zn stress on antioxidant enzyme activity in Lemna polyrrhiza $L$.
}

\section{Punita Parikh $\bowtie$ and Krupa Unadkat}

Received: 23.11.2013
Revised: 02.04.2014

Accepted: 28.04.2014

\begin{abstract}
The effect of deleterious concentration of zinc provided individually was investigated in order to assess the effect of metal interaction in Lemna polyrrhiza $L$. The present study also emphasizes on the response of catalase and guaiacol peroxidase enzymes under zinc stress. Both antioxidant enzymes exhibited an increasing trend under different treatment conditions but it was reverse at highly toxic metal concentration. The antioxidant activities of enzymes, i.e of catalase, ascorbate peroxidase, guaiacol peroxidase and their activity proportions were examined. Catalase activities were substantially increased in a stress environment as compared to guaiacol peroxidase. Further, catalase and showed increased activities in a combined stress environment. Physiological role of these enzymes in stress tolerance mechanism is discussed. The response of Lemna polyrrhiza $L$ to toxic concentrations of $\mathrm{Zn}$ appears to induce oxidative damage as observed by the increase antioxidant metabolism.
\end{abstract}

Keywords- Antioxidant, ascorbate peroxidase, catalase, enzyme activity, glutathione reductase, guaiacol peroxidase, Lemna polyrrhiza L. , stress

\section{Introduction}

Environmental stress factors like drought, temperature, high salinity and heavy metals are the major constraints that limit plant growth and productivity, by disturbing the intracellular water balance. Usually, in fields or on agricultural land, unlike in a laboratory or even a greenhouse environment, plants are subjected to a manifold array of stress factor (Siddiqui et al. 2008 and Nawaz et al. 2010).However, most of the studies have been devoted to assess the physiological response of plants in a single stress environment like salinity (Sinha 1991 and Sharma and Gills 1994, Kumar and Kumar 1996), drought (Shinozaki and Yamaguchi 2000) and heavymetals (Hameed et al. 2000 and Jetley et al, 2004). Studies on the physiological responses of plants under a combination of such stresses are restricted to just a few reports (Wang et al. 2003 and Dudley and Shani 2003, Wang and Huang 2004 and Jakab et al. 2005) and even they are not directly related to the combination of stress factors like heavy metal.

Plants have utilized various mechanisms to combat with abiotic stresses. Among them, stress tolerance gene expression, compatible solutes, phenols and antioxidant enzyme production are some examples Author's Address

Department of Botany, Faculty of Science, The Maharaja Sayajirao University of Baroda, Vadodara

Email: punitaparikh@gmail.com
(Jakab et al. 2005, Siddiqui and Khan 2011). Antioxidant enzymes such as superoxide dismutase (SOD) ascorbate peroxidase (APX), glutathione reductase, guaiacol peroxidase and catalase are well-known defense systems providing protection against the hazards of reactive oxygen species (ROS) in different stressful conditions (Allen et al. 1997, Kwon et al. 2002). These defenses may also involve water-soluble antioxidants such as ascorbate, glutathione and phenolic compounds and lipid-soluble molecules such as carotenoids and tocopherols (Foyer et al,1994; Hodges et al . 1997 and Hodges and Forney 2000; Pastori et al, 2000). Oxidative stress is characterized by the synthesis of hydrogen peroxide, which is detoxified by CAT activity in the peroxisomes and by APX in the cytosol, mitochondria and chloroplasts (Foyer et al. 1994 and Asada, 1999). On the other hand, antioxidant molecules such as glutathione, ascorbate and soluble phenolic compounds are able to directly scavenge reactive oxygen radicals and, in the case of ascorbate and glutathione, they are also substrates for the antioxidant enzymes APX and GPX, respectively. Therefore, it seems likely that both ascorbate and glutathione might play a key role in buffering oxidative stress in most eukaryotic systems (Noctor and Foyer, 1998; Smirnoff, 2000 and Smirnoff et al. 2001). 
Activities of these antioxidant enzymes are frequently observed in a single stress environment but the response and the proportion of the relative activities of these enzymes in a combined heavy metal (lead) environment have seldom been reported. To make up for this lack, the present study examines the response of antioxidant enzymes and the proportions of their relative activities in heavy metal (zinc sulphate) stress environment.

\section{Material and Methods Plant Material:}

The test plants Lemna polyrrhiza L. was collected from the pond at Harani, Vadodara (Fig 1 and 2). They were allowed to acclimatize for 15 days. Plants were washed thoroughly under a running tap water and were grown and propagated for 4 weeks in quarter strength Hoagland's solution (Hoagland and Arnon, 1950). Plants of same size were selected for the experiment. In the pilot scale experiment, the test plants were exposed to wide range of the metal ion concentrations i.e.10, 20, 30, 40, 50, 60, 70, 80, 90 and $100 \mathrm{ppm}$. It was noticed that the plants were unable to survive in the concentration range between 20-100 ppm Zn ions.

In the subsequent experiments it was revealed that the concentration mortality (LC50) of Zinc sulphate on exposed plants was $9 \mathrm{ppm}$ during 240 hrs. Therefore, the trace element under study $\mathrm{ZnSO}_{4}$ (Zn) were supplied at 1, 3, 5, 7 and 9 ppm for 3, 6 and 9 days. Nutrient solution devoid of trace element served as a control. Both the control and the treated solutions were maintained at $\mathrm{pH} 5.5$ using dilute $\mathrm{HCl}$ or $\mathrm{NaOH}$. Experimental plants (in triplicates) were placed in nutrient solution. Solutions were replenished every 3 days to prevent depletion of metals and nutrients. After each experimental period, harvested plants were washed in running tap water and rinsed with deionized water. Extraction and estimation of CAT and APX was followed the method of Thimmaiah, (1999).

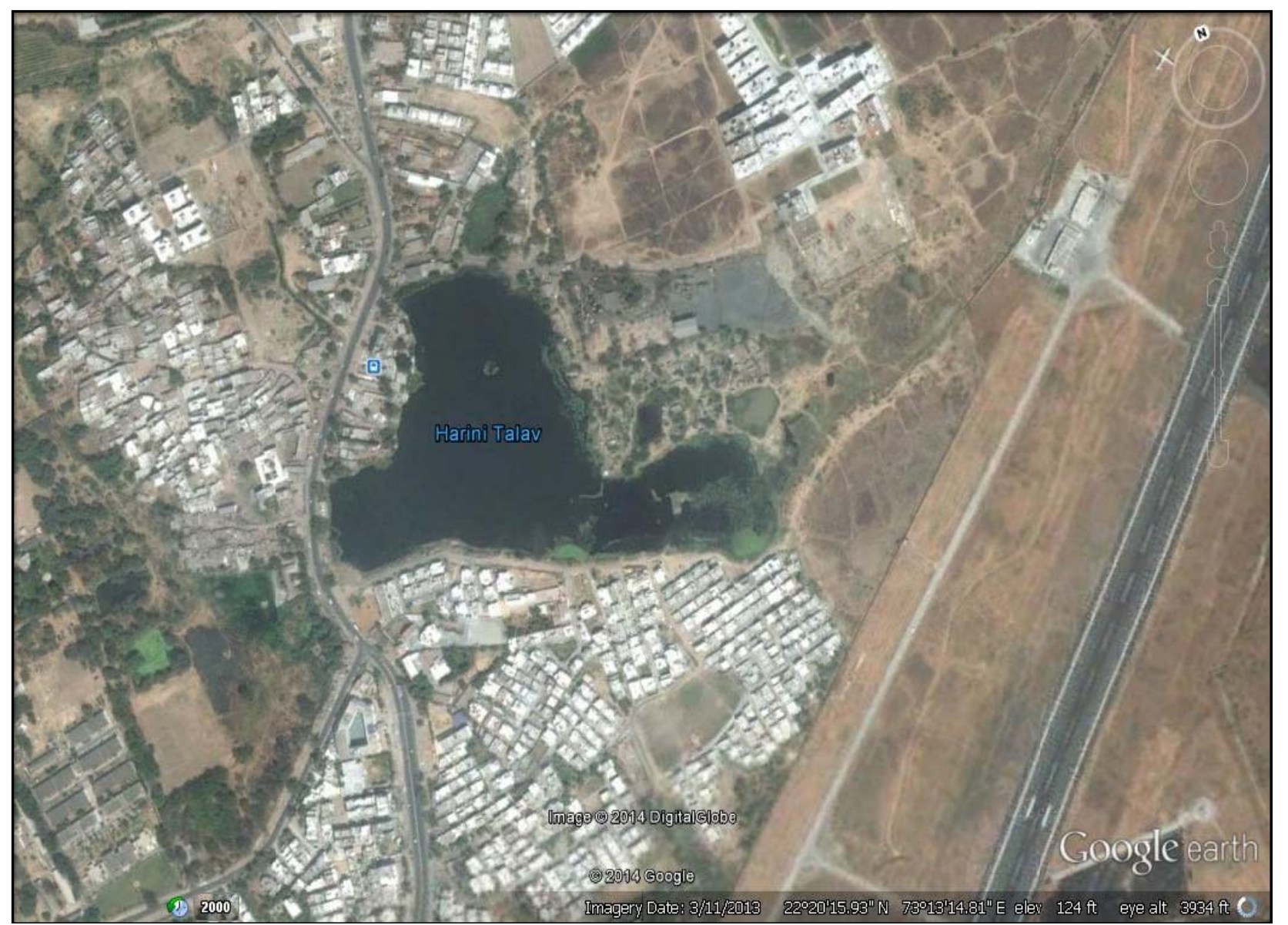

Fig 1: Map of Collection site 


\section{Enzyme Extraction and Assay:}

\section{Catalase}

Plants (100 mg) from each treatment were collected at 3, 6 and 9 days intervals and homogenized in 0.1 $\mathrm{M}$ sodium phosphate buffer (pH 7.0) and centrifuged at $1,000 \mathrm{~g}$ for $10 \mathrm{~min}$ at $4^{\circ} \mathrm{C}$. One $\mathrm{ml}$ of the supernatant was added to a reaction mixture containing $1 \mathrm{ml}$ of $0.1 \mathrm{M} \mathrm{H}_{2} \mathrm{O}_{2}$ and $3 \mathrm{ml}$ of $0.1 \mathrm{M}$ sodium phosphate buffer $(\mathrm{pH} 7.0)$. The reaction was stopped by adding $10 \mathrm{ml}$ of $2 \% \mathrm{H}_{2} \mathrm{SO}_{4}$ after 1 min incubation at $20^{\circ} \mathrm{C}$. The acidified reaction mixture with or without supernatant was titrated against $0.01 \mathrm{M} \mathrm{KMnO}_{4}$ to determine the quantity of $\mathrm{H}_{2} \mathrm{O}_{2}$ utilised by the enzyme. The catalase activity was expressed in enzyme units as $\mu \mathrm{mol} \mathrm{H}_{2} \mathrm{O}_{2}$ destroyed mg protein ${ }^{-1} \mathrm{~min}^{-1}$.

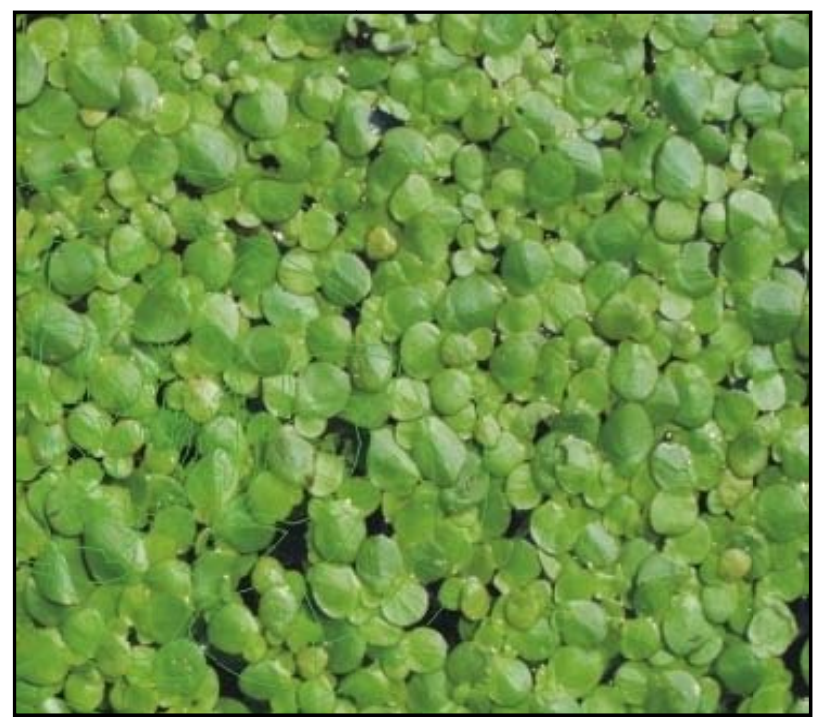

Fig 2: Lemna polyrhhiza

\section{Guaiacol Peroxidase}

Plants $(100 \mathrm{mg})$ from each treatment were collected at 2 week intervals and homogenized with mortar and pestle in cold $0.1 \mathrm{M}$ phosphate buffer ( $\mathrm{pH}$ 6.1). The homogenate was filtered and centrifuged at $12000 \mathrm{~g}$ for $10 \mathrm{~min}$ at $4^{\circ} \mathrm{C}$. The supernatant was used for the peroxidase assay. The assay mixture contained $0.1 \mathrm{M}$ phosphate buffer ( $\mathrm{pH} 6.1$ ), $4 \mathrm{mM}$ guaiacol, $3 \mathrm{mM} \mathrm{H} \mathrm{H}_{2} \mathrm{O}_{2}$ and $0.4 \mathrm{ml}$ of crude enzyme extract. The total reaction volume was $1.2 \mathrm{ml}$. The rate of change in absorbance (OD) at $420 \mathrm{~nm}$ was measured using a UV-Spectrophotometer (Jasco, UVIDEC-650, Japan). The levels of enzyme activity were expressed as $\mu \mathrm{mol} \mathrm{H}_{2} \mathrm{O}_{2}$ destroyed mg protein-1 min-1.

\section{Results and Discussion}

In the current research it was investigated that the activities of both catalase and peroxidase were significantly higher in tolerant plants in comparison with the uncontaminated ones (Fig. 3 and Fig 4.) Greater activities of catalase and Guaicol peroxidase indicated that the tolerant plant were under oxidative stress, a feature often associated with metal tolerance (Van and Clisters, 1990) Nashikkar and Chakrabarti, (1994) reported that both higher activity of catalase and peroxidase in crops grown on heavy metal polluted soil.
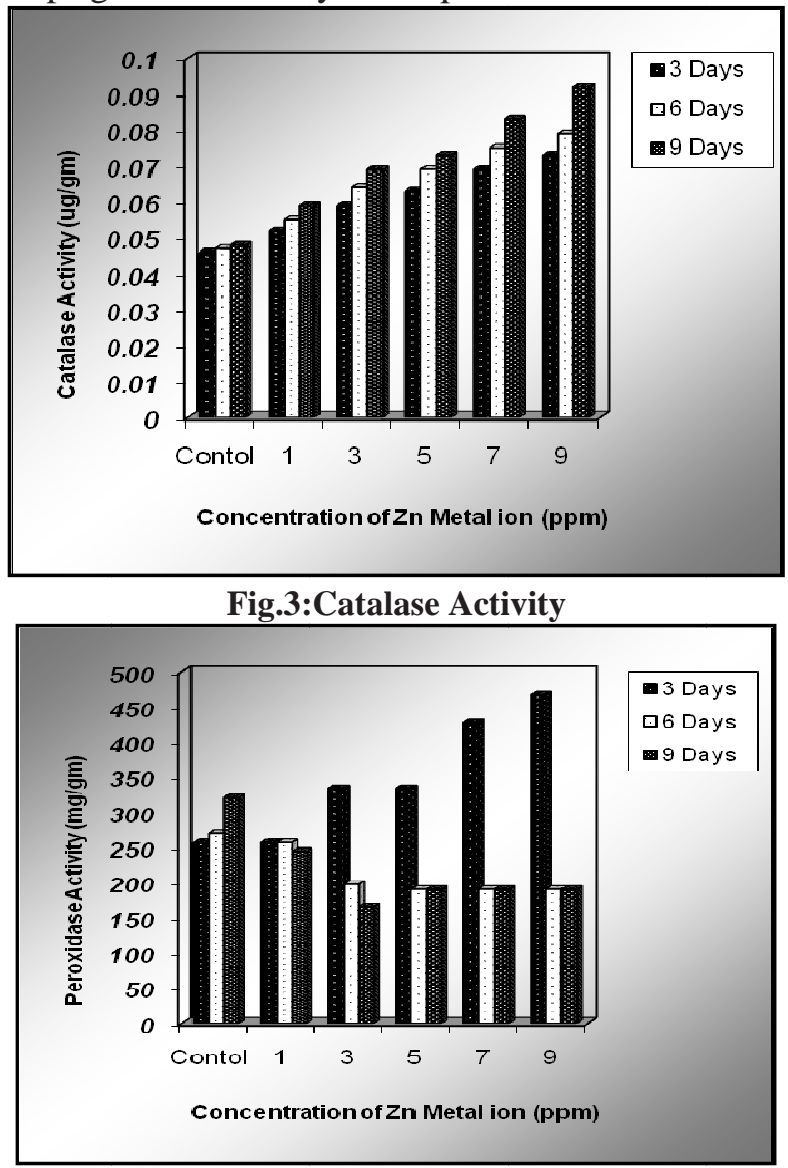

Fig: 4:Peroxidase activity

In the present investigation it was reported that activities of catalase enhanced linearly with increased metal ion concentration whereas the activity of guaicol peroxidase showed increase with metal ion concentration only at 3 day exposure period. Thereafter it decreased at 6 and 9 day exposure period. Heavy metals in soil, water and atmosphere, where plants are living are seen to demonstrate interactions between these heavy 
metals and the plants. On the other hand, heavy metals show negative effects on plants by inhibiting growth, damaging the structure, affecting the physiological and biochemical activities and decreasing the functions of the plants. The effects and bioavailability of heavy metals depends on many factors including environmental conditions such as $\mathrm{pH}$, species of heavy metals, and organic substances in the media as well as fertilization and the individual plant species. Plants have their own mechanisms of resistance against the negative effects of heavy metal by combining heavy metals with proteins and developing enzymes and nucleic acids to detoxify heavy metal pollution. Thus, the effects heavy metals on plants are revealed in several aspects and the plants show many kinds of resistance mechanisms. The changes in antioxidative enzyme activities in response to heavy metal stress are known to be dependent on heavy metal concentration (Shah et al.2001). Activities of these enzymes might increase in order to cope with the oxidative stress imposed by heavy metals on plants, as was repeatedly found in our experiments. Alternatively, they might be diminished if the toxic effects of higher concentration of heavy metals were greater than can be tolerated and combated by the antioxidant enzymes, as is the case in the present experiment, particularly catalase activity.

On the other hand, decreased activity of peroxidase in 6 and 9 days Zn treated plant indicated that the plants were under tremendous heavy metal stress. This might have resulted in the accumulation of ROS (reactive oxygen species). ROS products are reported to cause damage to the biomolecules by peroxidation, electrophilic substitution reaction, reduction of memberane lipids, proteins, chloroplast pigments, enzymes, nucleic acids etc. (Comba et al. 1998, Becana et al. 2000 and Majeed et al.2010). It is evident that each of $\mathrm{Zn}$ can separately cause significant reduction in most of the recorded structural parameters with detrimental physiological consequences. It might be concluded that exposure of L.poyrhhiza L. to toxic levels of $\mathrm{Zn}$ triggers a number of closely inter related $\mathrm{s}$ structural and functional events in the stressed plants.

\section{References}

Allen, R. D., Webb, R. P. and Schake, S. A. 1997: Use of transgenic plants to study antioxidant defenses. Free Radical Biology and Medicine. 23: 473-479.

Asada, K. 1997. The role of ascorbate peroxidase and monodehydroascorbate reductase in $\mathrm{H}_{2} \mathrm{O}_{2}$ scavenging in plants. In: Scandalios JG, ed. Oxidative stress and the molecular biology of antioxidant defenses. Cold Spring Harbor Laboratory Press, 715-735.

Becana, M., Dalton, D. A., Moran, J. F., Iturbe-Ormaetxe, I., Matamoros, M. A. and Rubio, M. C. 2000. Reactive oxygen species and antioxidants in legume nodules. Physiologia Plantarum 109: 372-81.

Comba, M. E., Benavides, M. P., Tomaro, M. L., 1998. Effect of salt stress on antioxidant defence system in soybean root nodules. Australian Jr. Plant Physiology 25: 665-671.

Dudley, L. M. and Shani, U., 2003. Modeling plant response to drought and salt stress: Reformulation of the root-sink term. Vadose Zone Jr. 2: 751-758.

Foyer, H. C., Lelandais, M., Kunert J.K., 1994. Photooxidative stress in plants. Physiologia Plantarum. 92 (4): 696-717.

Hameed, N., Siddiqui, Z. S. and Ahmed, S. 2000. Effect of copper and lead on germination, accumulation and phenolic contents of Spinancea oleracea and Lycopersicum esculentum. Pakistan Jr. Bio. Sci. 4: 809-811.

Hoagland, D. R. and Arnon, D. I. 1950. The water-culture method for growing plants without soil. Circular 347, University of Californias, Agricultural Experimental Station, Berkley, 1-32.

Hodges D.M. and Forney C.F. 2000. The effect of ethylene, depressed oxygen and elevated carbon dioxide on antioxidant profiles of senescing spinach leaves. Jr. Exp. Bot. 5: 645-655.

Hodges D.M., Andrews C.J., Johnson D.A. and Hamilton R.I. 1997. Antioxidant enzyme responses to chilling stress in differentially sensitive inbred maize lines. Jr. Exp. Bot. 48: 1105-1113.

Jakab, G., Ton, J., Flors, V., Zimmerli, L., Metraux, J. P. and Mauch-Mani, B. 2005. Enhancing Arabidopsis salt and drought stress tolerance by chemical priming for its abscisic acid responses. Plant Physio 139: 267-274.

Jetley, U. K., Choudhary, M. and Fatma, T. 2004. Evaluation of biochemical productivity cyonobacterium Spirulina platensis-S5 under heavy metal stress. Asian Jr. Chem. 16: $1524-1528$.

Kumar, V and Kumar, D. 1996. Response of Indian mustard to saline water application at different growth stages. Trans Indian Society Desert Technology 15: 121-125. 
Kwon, S. Y., Jeong, Y. J.,Lee, H. S.,Kim, J. S.,Cho, K. Y.,Allen, R. D. and Kwak, S. S. 2002. Enhanced tolerances of transgenic tobacco plants expressing both superoxide dismutase and ascorbate peroxidase in chloroplasts against methyl viologen-mediated oxidative stress. Plant Cell Environ. 25: 873-882.

Majeed, A., Nisar, M. F. and Hussain, K. 2010. Effect of saline culture on the concentration of $\mathrm{Na}^{+}, \mathrm{K}^{+}$and $\mathrm{Cl}^{-}$in Agrostis tolonifera. Current Research Jr. Bio. Sci. 2: 76-82.

Nashikkar V.J. and Chakrabarti T. 1994. Catalase and peroxidase activity in plants - an indicator of heavy metal toxicity. Indian Jr. Exp. Bio. 32: 520-521.

Nawaz, K., Hussain, K., Majeed, A., Faraha, K., Shahida, A. and Kazim, A. 2010. Fatality of salt stress to plants: Morphological, physiological and biochemical aspects. African Jr. of Biotech. 9: 5475-5480.

Noctor G. and Foyer C.H. 1998. Ascorbate and glutathione: keeping active oxygen under control. Annual Review of Plant Physio. and Plant Mol. Bio. 49: 249-279.

Pastori G., Foyer C.H. and Mullineaux P. 2000. Low temperature induced changes in the distribution of $\mathrm{H}_{2} \mathrm{O}_{2}$ and antioxidants between the bundle sheath and mesophyll cells of maize leaves. Jr. Exp. Bot. 51: 107-113.

Shah, K., Kumar, R. G., Verma, S. and Dubey, R. S. 2001. Effect of cadmium on lipid peroxidation, superoxide anion generation and activities of antioxidant enzymes in growing rice seedlings. Plant Sci. 161: 1135-1144.

Sharma, P. C. and Gill, K. C. 1994. Salinity-induced effect on biomass, yield, yield attributing characters and ionic contents in genotypes of Indian mustard. Indian Jr. of Agri. Sci. 64: 785-788.
Shinozaki, K. and Yamaguchi-Shinozaki, K. 2000. Molecular responses to dehydration and low temperature: differences and cross-talk between two stress signaling pathways. Current Opinion in Plant Bio. 3: 217-223.

Sinha, T. S. 1991. Genetic adaptation of Indian mustard to semiarid saline-soil condition. Indian Jr. of Agri. Sci. 61: 251-254.

Siddiqui, Z. S., Khan, M. A., Beomgi, K., Huang, J-S. and Kwon, T. R. 2008. Physiological response of Brassica napus genotypes in combined stress. Plant Stress 2: 78-83.

Siddiqui, Z. S. and Khan, M. A. 2011. The role enzyme amylase in two germinating seed morphs of Halophyrum mucronatum (L.) Stapf in saline and non-saline environment. Acta Physiologea Plantrum 33: 1185-1197.

Smirnoff , N. 2000. Ascorbic acid: metabolism and functions of a multi-facetted molecule. Current Opinion in Plant Bio. 3: 229-235.

Smirnoff N., Conklin, P.L. and Loewus, F.A. 2001. Biosynthesis of ascorbic acid in plants: a renaissance. Annual Review of Plant Physio and Plant Mol. Bio. 52: 437-467.

Thimmaiah 1999. Standard methods of biochemical analysis. Kalayni publisher, NewDelhi.

Van Assche, F. and Clijsters, H. 1990. Effects of metals on enzyme activity in plants. Plant, Cell and Environ., 13(3): 195-206

Wang, W., Vinocur, B. and Altman, A. 2003. Plant responses to drought, salinity and extreme temperatures: towards genetic engineering for stress tolerance. Planta 18: 1-14.

Wang, Z. and Huang, B. 2004. Physiological recovery of Kentucky bluegrass from simultaneous drought and heat stress. Crop Science 44: 1729-1736. 